\title{
Tetraclita ehsani sp. n. (Cirripedia, Tetraclitidae), a common intertidal barnacle from the Gulf of Oman, Iran
}

\author{
Adnan Shahdadi ${ }^{1, \dagger}$, Benny K.K. Chan ${ }^{2, \ddagger}$, Alireza Sari ${ }^{3, \S}$ \\ University of Tehran, Tehran, Iran \\ † urn:lsid:zoobank.org:author:E8CD2E08-039B-489B-AOEB-ODA4835C66D4 \\ † urn:lsid:zoobank.org:author:8C3C6E7D-96C0-4E60-BF2B-DF76E03CE0BD \\ § urn:lsid:zoobank.org:author:7210357C-576D-4F55-96B1-345912557C92 \\ Corresponding author: Benny K.K. Chan (chankk@gate.sinica.edu.tw)
}

I Department of Biology, Faculty of Science, University of Hormozgan, Bandarabbas, Iran 2 Biodiversity Research Center, Academia Sinica, Taipei 115, Taiwan 3 Zoological Museum, School of Biology, College of Science,

Academic editor: Niel Bruce | Received 2 July 2011 | Accepted 12 September 2011 | Published 13 October 2011

urn:lsid:zoobank.org:pub:B0A49CE2-AE7F-4140-BB5B-7DA11B75DOF2

Citation: Shahdadi A, Chan BKK, Sari A (2011) Tetraclita ehsani sp. n. (Cirripedia, Tetraclitidae), a common intertidal barnacle from the Gulf of Oman, Iran. ZooKeys 136: 1-12. doi: 10.3897/zookeys.136.1772

\begin{abstract}
A new species of intertidal acorn barnacle Tetraclita ehsani $\mathbf{s p .} \mathbf{n}$. was identified from the Iranian coast in the Gulf of Oman. T. ehsani sp. n. inhabits low exposed rocky shores and also attaches to shells of molluscs and the barnacle Megabalanus species. Parietes of T. ehsani ranged from white to pink which is different from T. serrata (in South African waters), which has green parietes. Morphology of the tergum and cirrus III of T. ehsani sp. n. is distinctive from other described West Indian Ocean species which have pink or white parietes (T. rufotincta, T. achituvi and T. reni). The tergum of T. ehsani is very narrow and the basal margin is slightly concave or straight, in contrast to T. rufotincta and T. reni, in which the tergum are board and with a very concave basal margin. Cirrus I anterior ramus of both T. ehsani and T. reni is antenniform and thus differing from the cirrus I of T. rufotincta (see Chan et al. 2009). Cirrus III of T. ehsani sp. $\mathbf{n}$. is non-antenniform and lacks multicuspidate type setae, which is different from T. reni by having an antenniform cirrus III and with multicuspidate setae.
\end{abstract}

\section{Keywords}

Crustacea, Cirripedia, Tetraclitidae, barnacles, Indian Ocean, Gulf of Oman, Iran

Copyright Adnan Shahdadi et al. This is an open access article distributed under the terms of the Creative Commons Attribution License, which permits unrestricted use, distribution, and reproduction in any medium, provided the original author and source are credited. 


\section{Introduction}

Tetraclita species are common rocky intertidal acorn barnacles in the tropical and subtropical waters of the world (Newman and Ross 1976). Tetraclita squamosa Bruguière, 1789 had been recorded worldwide and was considered to be composed of nine sub-species due to high degree of morphological variations (Newman and Ross 1976). Tetraclita squamosa has since been split into 23 species using morphological and molecular approaches (Chan et al. 2007a, b, c), but the taxonomy of the species in the West Indian Ocean has still received scant attention (Chan et al. 2009). Pilsbry (1916) described Tetraclita rufotincta (= Tetraclita squamosa rufotincta Pilsbry, 1916) from Yemen and Zanzibar, and designated Yemen as the type locality. T. rufotincta was subsequently recorded in the northwest coast of India (Wagh 1971, 1972), the Red Sea (Achituv and Barnes 1978) and the Persian Gulf (Utinomi 1969). Ross (1999) additionally described T. achituvi Ross, 1999 and T. barnesorum Ross, 1999 from T. rufotincta in the Red Sea but subsequent molecular studies (Appelbaum et al. 2002) revealed T. barnesorum was a synonym to T. rufotincta. Ren (1989) described T. africana from Madagascar, but as this name was preoccupied and it was renamed T. reni Chan, Hsu \& Tsai, 2009 by Chan et al. (2009). In the West Indian Ocean, T. reni is distributed in southern Madagascar and adjacent waters (Chan et al. 2009).

Taxonomic studies of Iranian barnacles after Utinomi (1969) are scant (Jones 1968; Southward and Newman 2003). Recently, extensive barnacle collections was carried out by Shahdadi (2007), Shahdadi and Sari (2011) on intertidal barnacles of the Persian Gulf and Gulf of Oman. Tetraclita rufotincta is common in the intertidal of the Persian Gulf (Shahdadi 2007). However, Tetraclita specimens collected from exposed rocky shores at the Gulf of Oman, Iran were morphologically different from other known Tetraclita species of the West Indian Ocean, suggesting that this is a new species. The Tetraclita specimens from the Gulf of Oman were examined by one of us (BKK Chan) using COI molecular markers, which showed a large genetic divergence from all known species in the West Indian Ocean (sequence of Tetraclita specimen from Gulf of Oman submitted to GenBank, unpublished data for phylogenetic comparisons). This further confirms the Tetraclita collected from the Gulf of Oman is a new species and described herein.

\section{Materials and methods}

Tetraclita specimens were collected from the low intertidal shores at Ramin, Chabahar $\left(25^{\circ} 16^{\prime} \mathrm{N}, 60^{\circ} 44^{\prime} \mathrm{E}\right)$ and Tis, Chabahar Bay (25 $\left.16^{\prime} \mathrm{N}, 60^{\circ} 40^{\prime} \mathrm{E}\right)$, Gulf of Oman, Iran. Barnacles were preserved in 95\% Ethanol upon collection. The opercular plates, cirri and mouth parts were dissected and observed under compound light microscopes. The first three pairs of cirri and mouth parts were further investigated using a FEI Quanta 200 Scanning Electron Microscope (SEM) following Chan et 
al. (2007a, c, 2009). Terminology in describing the setae follows Chan et al. (2008). The COI barcode region was sequenced from the somatic body of the Tetraclita (paratype, ASIZCR 000231) collected from Chabahar, Gulf of Oman. DNA extraction and PCR protocol followed Chan et al. (2007a, c) and sequence was deposited in the GenBank.

The holotype and two paratypes are deposited in the Zoological Museum, University of Tehran (ZUTC) and one of the paratype was deposited in the Biodiversity Museum, Academia Sinica, Taiwan (ASIZCR).

\section{Systematics}

\section{Superfamily Tetraclitoidea Gruvel, 1903 \\ Family Tetraclitidae Gruvel, 1903 \\ Tetraclitinae Gruvel, 1903 \\ Tetraclita Schumacher, 1817}

\section{Tetraclita ehsani sp. n.}

urn:lsid:zoobank.org:act:9829EE59-762C-4557-81AE-CB51DA038234

http://species-id.net/wiki/Tetraclita_ehsani

Figures 1-5

Material examined. HOLOTYPE. ZUTC-Cirri 1275, 1 specimen, Ramin, Chabahar, Gulf of Oman, Iran $\left(25^{\circ} 16^{\prime} \mathrm{N}, 60^{\circ} 44^{\prime} \mathrm{E}\right)$, basal carino-rostro diameter $19.64 \mathrm{~mm}$, height $13.74 \mathrm{~mm}$, orifice diameter $5.24 \mathrm{~mm}$. PARATYPE. ASIZCR 000231, 1 specimen, locality same as holotype, basal carino-rostro diameter $18.16 \mathrm{~mm}$, height 11.91 $\mathrm{mm}$, orifice $5.78 \mathrm{~mm}$. PARATYPE. ZUTC-Cirri. 1276, 1 specimens, locality same as holotype. from Ramin (type locality). PARATYPE. ZUTC-Cirri. 1277, 1 specimen,

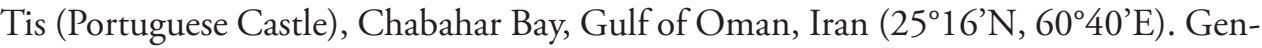
Bank accession number of paratype ASIZCR 000231: JN603678.

Diagnosis. Parietes white or pink, tergum very narrow, basal margin slightly concave or almost straight, tergal spur long and narrow. Mandible with five teeth, labrum with 4 large sharp teeth on each side of the cutting edge. Anterior ramus of cirrus I antenniform.

Description. Parietes conical, white to pink or white with pink ribs (Fig. 1A), radii and alae narrow, sheath striate, parallel to base and about $1 / 2$ height of wall, sheath white to dirty white, or pink. Parietes composed of 3-4 rows of honey comb parietal tubes (Fig. 1B). Scutum and tergum white (Fig. 1B, C, D). Scutum narrow, 1.5 times higher than wide, lower half of occludent margin with $>10$ oblique teeth, articular ridge sinuous, adductor ridge extremely developed, angular and extending to basal margin, adductor muscle pit shallow, seven distinct rostral and four to six lateral depressor crests (Fig. 1B, C, D), external surface smooth with faint horizon- 


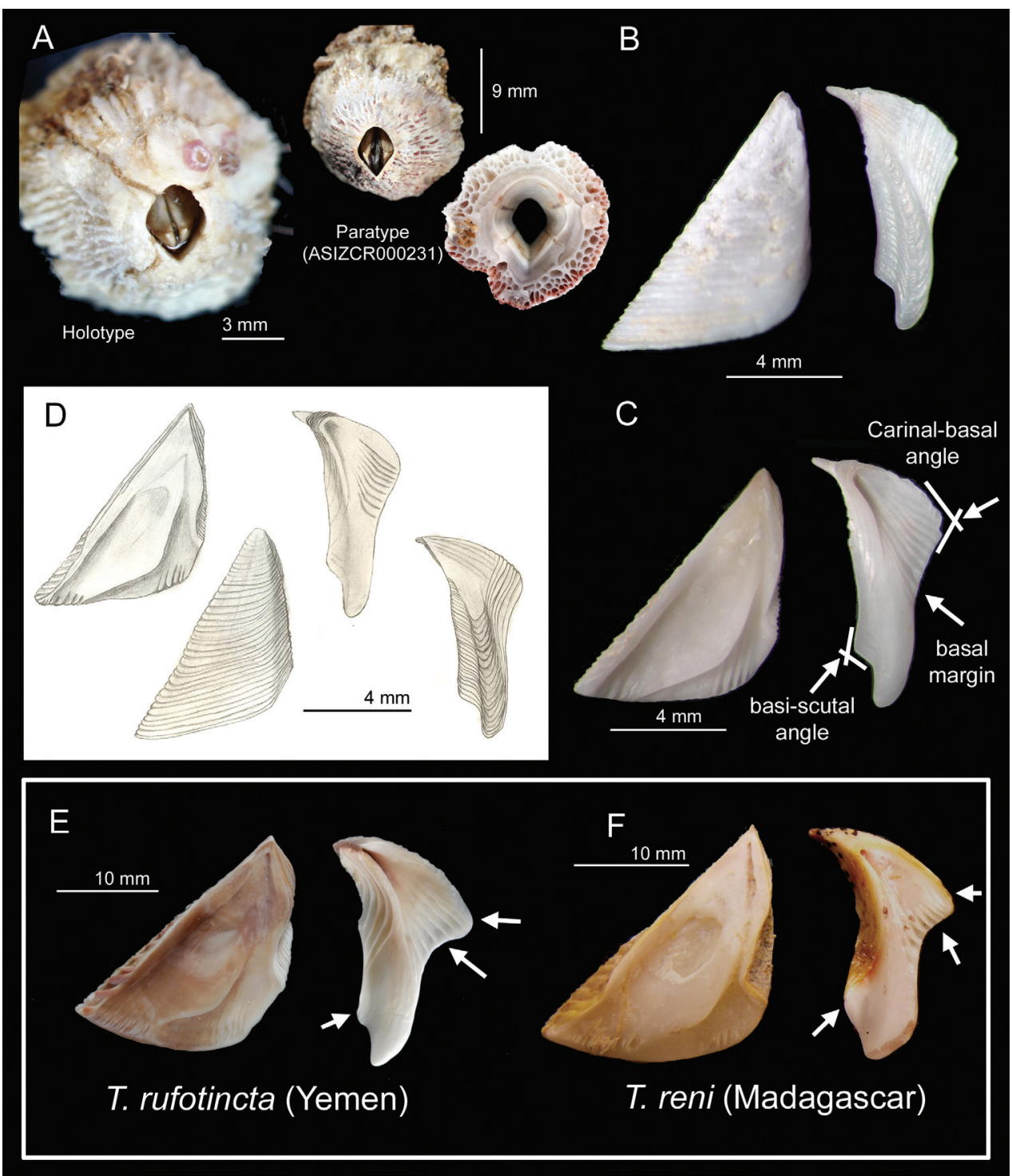

Figure I. Tetraclita ehsani sp. n. A external parietes of the holotype and the top and basal view of the parietes of a paratype (ASIZCR 000231); note the basal view showing the parietal tubes B external view of scutum and tergum of the paratype (ASIZCR 000231) C internal view of scutum and tergum, (ASIZCR 000231); arrows indicate the diagnostic features of tergum from other Western Indian Ocean species (see table 1) D drawing of the holotype of the scutum and tergum E Scutum and tergum of Tetraclita rufotincta collected from Yemen (type locality) (after Chan et al. 2009) F scutum and tergum of Tetraclita reni collected from Madagascar (type locality) (after Chan et al. 2009).

tal striations (Fig. 1). Tergum long and narrow (length more than twice as width) with ten definite depressor crests, scutal margin slightly concave, spur long and narrow, external spur surface with a medial furrow, basi-scutal angle sharp and about 


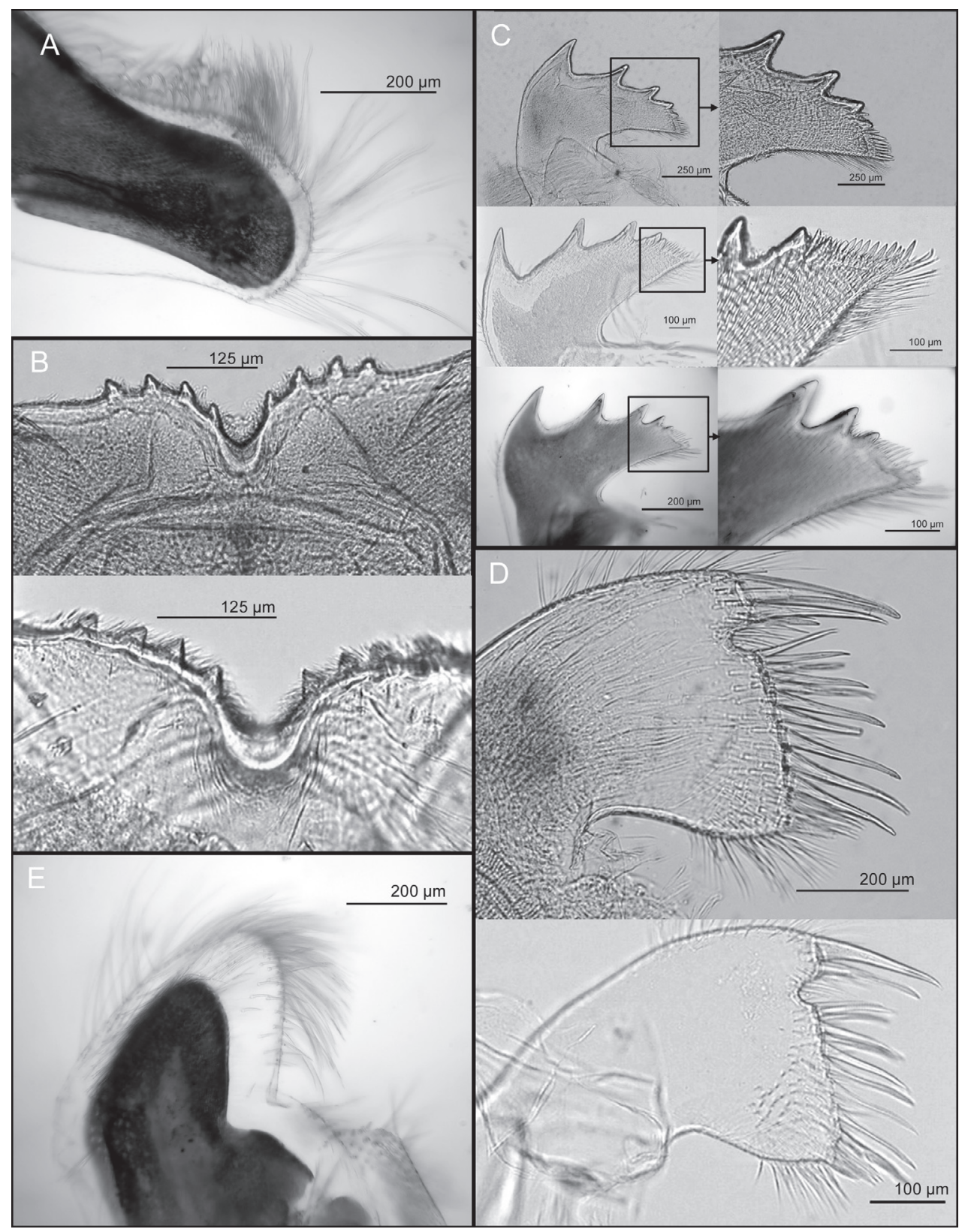

Figure 2. Tetraclita ehsani sp. n. Light microscopy showing: A mandibular palp B labrum (two individuals) $\mathbf{C}$ mandibles (3 individuals) and with enlarged views of lower margin and inferior angle $\mathbf{D}$ maxillule (2 individuals) and $\mathbf{E}$ maxilla.

$117.8^{\circ}$, upper carinal margin convex and basal margin slightly concave or straight (Fig. 1B, C, D). Carinal-basal angle (angle between the carinal and basal margin) is $-103^{\circ}$ (Fig. 1C). 

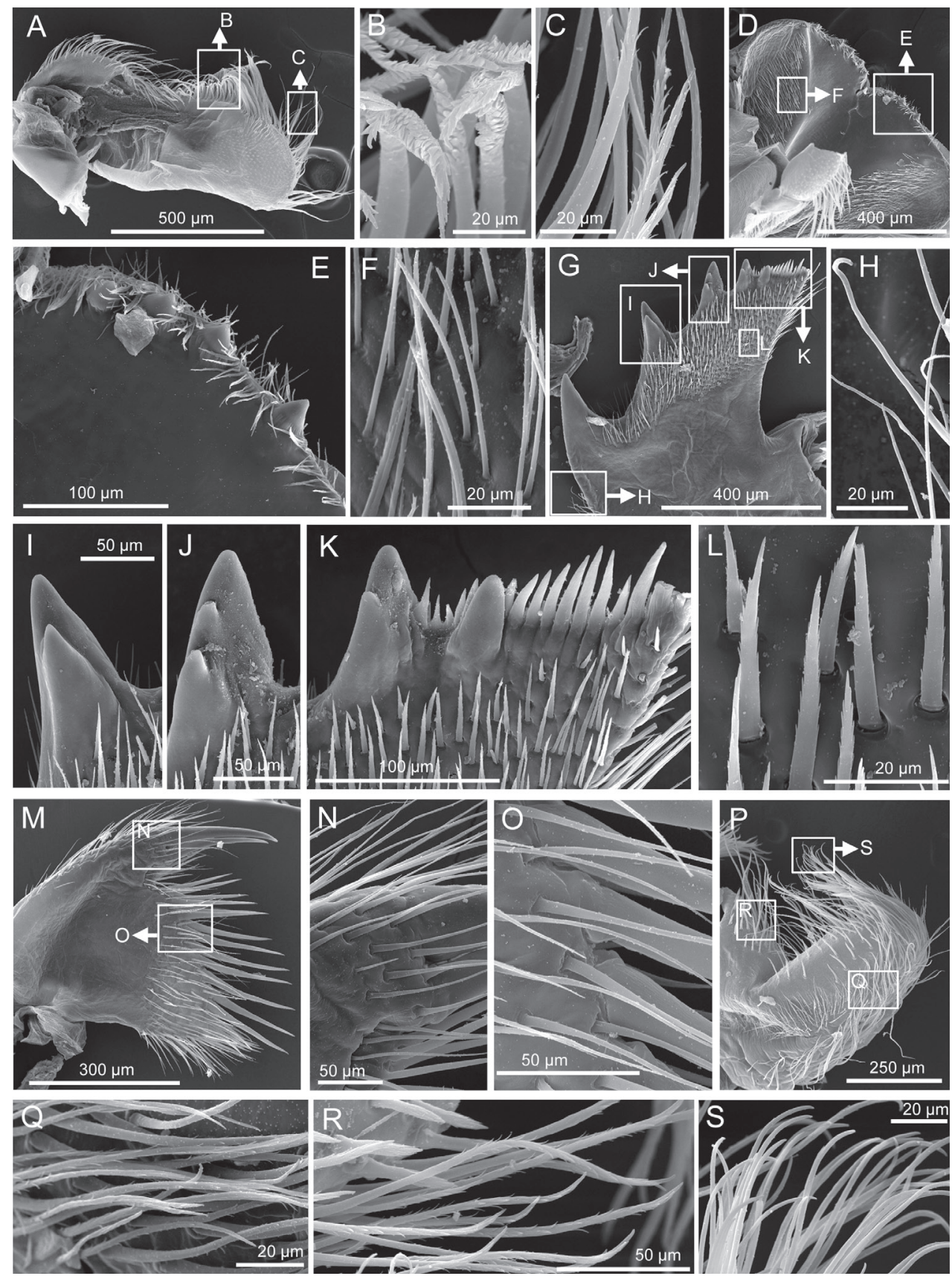

Figure 3. Tetraclita ehsani sp. n. SEM showing: A mandibular palp B, C serrulate type setae on mandibular palp D labrum $\mathbf{E}$ cutting edge of labrum showing the 4 large sharp teeth $\mathbf{F}$ simple type setae on inner side of labrum $\mathbf{G}$ mandible $\mathbf{H}$ simple setae on the lateral side of the mandible $\mathbf{I}$ second bi-dentated tooth of the mandible J third tri-dentated tooth of the mandible $\mathbf{K}$, fourth and fifth tooth of the mandible $\mathbf{L}$, serrulate blade shaped setae on mandible $\mathbf{M}$ Maxillule $\mathbf{N}, \mathbf{O}$ serrulate setae on maxillule surface $\mathbf{P}$ maxilla $\mathbf{Q}, \mathbf{R}$, serrulate setae on maxilla $\mathbf{S}$ simple setae on tip of maxilla. 


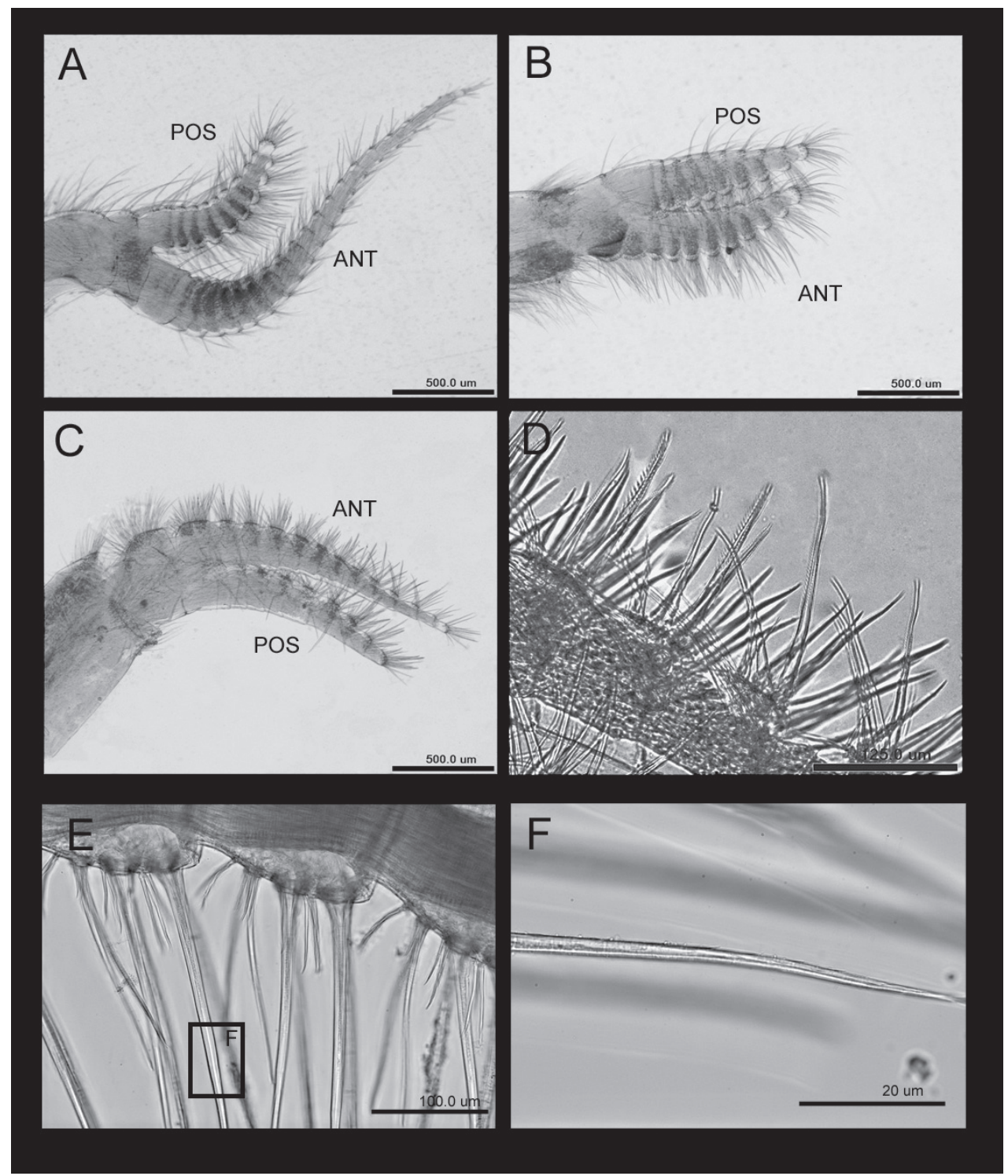

Figure 4. Tetraclita ehsani sp. n. Light microscopy showing: A cirrus I B cirrus II C cirrus III D bidentate serrulate type setae on rami of cirrus III $\mathbf{E}$ intermediate segment of anterior ramus of cirrus VI F Long serrulate setae at cirrus VI. ANT - Anterior ramus, POS - Posterior ramus.

Mandibular palps elongate, setae on superior margin only, simple type setae at tip and serrulate setae at the middle region of the superior margin (Figs 2A, 3A, B, C). Labrum notched, notch shallow, four erect large teeth on each side of the cutting edge (Figs 2B, 3E-H). Mandible with five teeth excluding the inferior angle, first tooth separated from the remaining teeth, second and fourth teeth bidentate, third teeth tridentated fifth tooth small and located close to the fourth tooth, lower margin with 

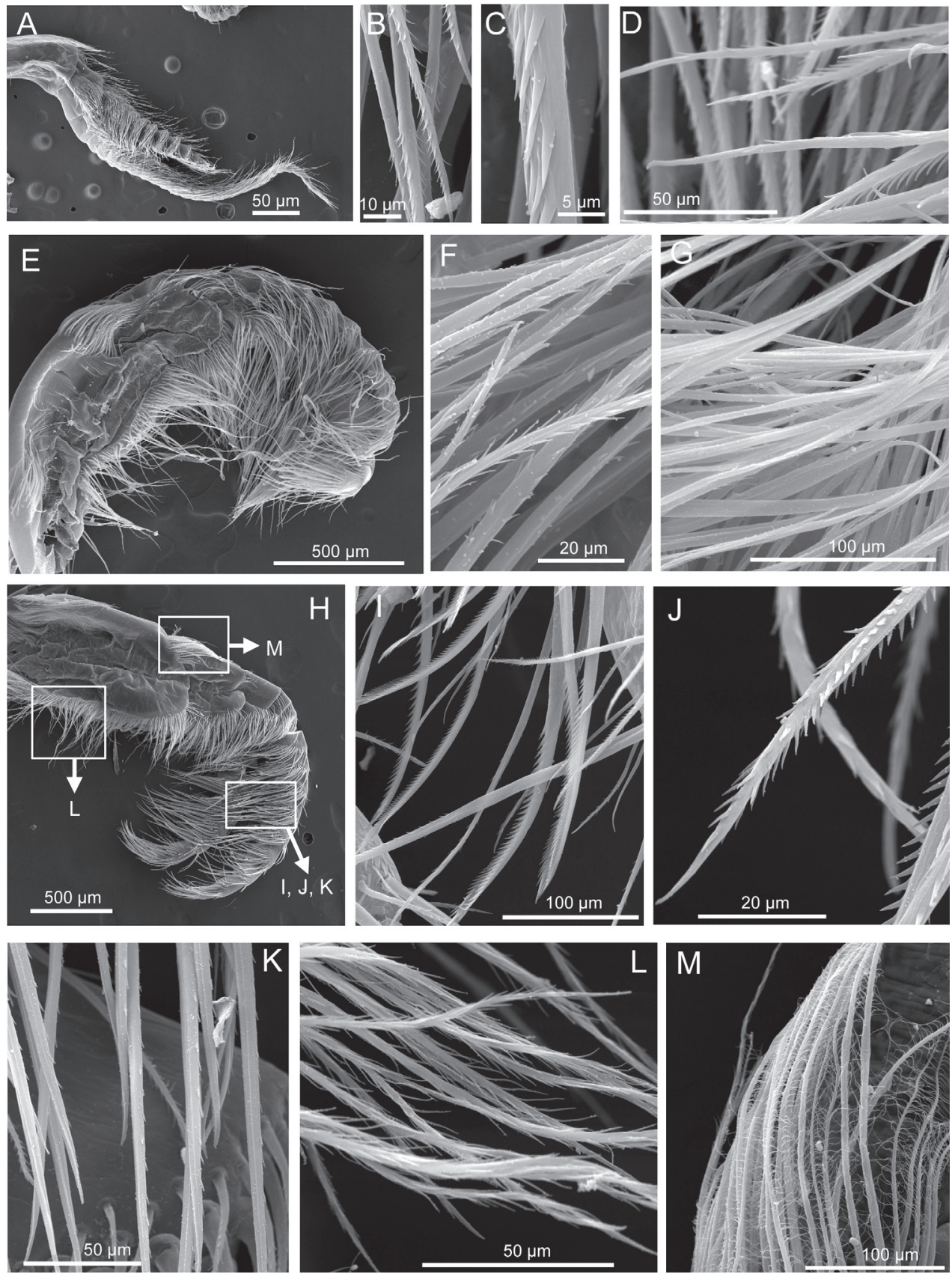

Figure 5. Tetraclita ehsani sp. n. SEM showing: A cirrus I B, C, D, serrulate type setae on rami of cirrus I $\mathbf{E}$ cirrus II $\mathbf{F}, \mathbf{G}$ serrulate type setae on rami of cirrus II $\mathbf{H}$ cirrus III $\mathbf{I}, \mathbf{J}, \mathbf{K}$, serrulate type setae on rami of cirrus III $\mathbf{L}$ serrulate type setae on protopod of cirrus III $\mathbf{M}$ pappose setae on protopod of cirrus III. 
$>10$ setae, height of setae similar to height of the fifth tooth, inferior angle sharp, with two large setae on tip, mandible surface with blade shaped serrulate type setae (Figs 2C, 3G-L). Maxillule notched, with two large and four small simple setae above notch, 11 setae in median cluster and 10 small and slender simple setae on the cutting margin below notch (Figs 2D, 3M-O). Maxilla bi-lobed, serrulate type setae at both lobes (Figs 2E, 3P-S).

Cirrus $I$ anterior ramus antenniform, twice as long (27 segments) as posterior ramus (10 segments) (Figs 4, 5A), both rami with a feathery serrulate type setae (3-4 rows dense setules in each seta) and a serrulate type setae (very sparse setule along the seta) (Fig. 5B-D). Cirrus II with shorter rami, anterior and posterior ramus similar in length (each with 10 segments), with serrate and simple setae (Fig. 5E-G). Cirrus III with longer anterior ramus (anterior and posterior ramus 13 and nine segments respectively; Fig. 4). Both rami bear bidentate serrate setae, feathery serrulate setae and blade shaped serrulate setae, protopod bears pappose setae with long feather seta (Fig. $5 \mathrm{H}-\mathrm{M})$. Cirrus $I V-V I$ ctenopods, cirrus IV with 17 segments for both anterior and posterior rami, cirrus $\mathrm{V}$, anterior ramus 21 segments, posterior ramus 19 segments, cirrus VI, anterior ramus 18 segments, posterior ramus 22 segments. Intermediate segment of anterior ramus of cirrus VI bears 3 pairs of long serrulate setae and 3 pairs of short setae (Fig. 4E, F).

Etymology. This species is named in honour of Ehsan Entezari-Zarch, B.Sc. student in Animal Biology at the University of Tehran, who unfortunately passed away during a field collection in October 2009.

Habitat. This species was present at the exposed low shores at intertidal zone, attaching on rocks but sometimes were observed on mollusk shells and on the shell surface of the barnacle Megabalanus species at the Gulf of Oman.

Distribution. At present, only known from the Iranian coast in the Gulf of Oman and absent from the Persian Gulf (see Shahdadi 2007).

\section{Discussion}

Tetraclita ehsani sp. n., from Iranian waters, shows diagnostic morphological characters that distinguish it from other known species in the Western Indian Ocean ( $T$. rufotincta, T. reni, T. achituvi and T. serrata). All the Tetraclita in the West Indian Ocean have white to pink parietes except T. serrata Darwin, 1854 which has green parietes. In addition to the colour of the parietes, T. serrata has serrated lines on parietes surface and with a broader spur in tergum, when compared to Tetraclita ehsani. It is difficult to distinguish T. ehsani from T. reni, T. achituvi and T. rufotincta using the external shell morphology. T. ehsani can be, however, distinguished from the other species by the tergum morphology and arthropodal characters. The ter- 
Table I. Morphological comparison of Tetraclita ehsani sp. n. with other Tetraclita from the west Indian Ocean. T. serrata was not included into comparison as the shell colour of T. serrata is green, which is obviously different from other West Indian Ocean species. For morphology features of T. rufotincta, T. reni and T. achituvi, see Pilsbry (1916), Chan et al. (2009) and Ross (1999).

\begin{tabular}{|c|c|c|c|c|}
\hline Characters & $\begin{array}{l}\text { Tetraclita ehsani } \\
\text { sp. n. }\end{array}$ & $\begin{array}{l}\text { T. rufotincta } \\
\text { Pilsbry, } 1916\end{array}$ & $\begin{array}{l}\text { T. reni Chan et } \\
\text { al., } 2009\end{array}$ & $\begin{array}{l}\text { T. achituvi } \\
\text { Ross, } 1999\end{array}$ \\
\hline Shell colour & White to pink & Pink to grey & White to pink & Pink to white \\
\hline $\begin{array}{l}\text { Tergum colour } \\
\text { and length }\end{array}$ & $\begin{array}{l}\text { White, twice longer } \\
\text { than wide }\end{array}$ & $\begin{array}{l}\text { Yellow to pink, } \\
\text { longer than wide } \\
\text { (less than twice) }\end{array}$ & $\begin{array}{l}\text { Yellow to pink, } \\
\text { longer than wide } \\
\text { (less than twice) }\end{array}$ & $\begin{array}{l}\text { White, } \\
\text { longer than wide } \\
\text { (about twice) }\end{array}$ \\
\hline Tergum Spur & $\begin{array}{l}\text { Longer than wide } \\
(-1.2 \text { times })\end{array}$ & $\begin{array}{l}\text { Wider than long } \\
(-1.2 \text { times })\end{array}$ & $\begin{array}{l}\text { Wider than long } \\
\text { (about twice) }\end{array}$ & $\begin{array}{l}\text { Wider than long } \\
\text { (1.5 times) }\end{array}$ \\
\hline $\begin{array}{l}\text { Basal margin of } \\
\text { tergum }\end{array}$ & $\begin{array}{l}\text { Slightly concave } \\
\text { with no clear angle }\end{array}$ & $\begin{array}{l}\text { Strongly concave, } \\
\text { forming almost } \\
\text { right angle }\end{array}$ & $\begin{array}{l}\text { Strongly concave, } \\
\text { forming almost } \\
\text { right angle }\end{array}$ & Slightly concave \\
\hline $\begin{array}{l}\text { Adductor muscle } \\
\text { pit in scutum }\end{array}$ & shallow & deep & shallow & deep \\
\hline $\begin{array}{l}\text { Adductor ridge in } \\
\text { scutum }\end{array}$ & $\begin{array}{l}\text { Extremely } \\
\text { developed, angular } \\
\text { and extending to } \\
\text { basal margin }\end{array}$ & $\begin{array}{l}\text { Developed but not } \\
\text { extending to basal } \\
\text { margin }\end{array}$ & $\begin{array}{l}\text { Developed but not } \\
\text { extending to basal } \\
\text { margin }\end{array}$ & $\begin{array}{l}\text { Extremely } \\
\text { developed }\end{array}$ \\
\hline Labrum teeth & $\begin{array}{l}\text { Four, large, sharp } \\
\text { and erect on each } \\
\text { side of notch }\end{array}$ & $\begin{array}{l}\text { Absent or four } \\
\text { small blunt on } \\
\text { cutting margin }\end{array}$ & $\begin{array}{l}\text { Four small blunt } \\
\text { teeth at each side } \\
\text { of the cutting } \\
\text { margin }\end{array}$ & $\begin{array}{l}\text { Six small teeth in } \\
\text { notch }\end{array}$ \\
\hline Cirrus III & $\begin{array}{l}\text { Non-antenniform, } \\
\text { without } \\
\text { multicuspidate setae }\end{array}$ & $\begin{array}{l}\text { Non-antenniform, } \\
\text { without } \\
\text { multicuspidate } \\
\text { setae }\end{array}$ & $\begin{array}{l}\text { Antenniform, with } \\
\text { multicuspidate } \\
\text { setae }\end{array}$ & $\begin{array}{l}\text { Antenniform, } \\
\text { without } \\
\text { multicuspidate } \\
\text { setae }\end{array}$ \\
\hline
\end{tabular}

gum of $T$. ehsani is very narrow and the basal region is slightly concave or almost straight, contrasting to the tergum of T. rufotincta and T. reni, which are board and with a strongly concave basal margin (Fig. 1E, F). The basi-carinal angle of T. ehsani sp. n. is $-100^{\circ}$, which is larger than that in T. reni $\left(80^{\circ}\right)$ and T. rufotincta $\left(73^{\circ}\right.$; Fig. $1 \mathrm{C}, \mathrm{D}, \mathrm{E})$. The basi-scutal angle of the tergum of $T$. ehsani is $\sim 120^{\circ}$, more angular than that of T. reni $\left(150^{\circ}\right.$ ) (Fig. 1C, D, E; see Chan et al. 2009). Anterior ramus of the cirrus I of both T. ehsani and T. reni is antenniform, thus differing from $T$. rufotincta (see Chan et al. 2009). Cirrus III T. ehsani sp. n. is non-antenniform and lacks multicuspidate setae, which is different from T. reni, in which the both anterior and posterior rami are antenniform and possess multicuspidate setae (see Chan et al. 2008) (Table 1).

The biogeography of Tetraclita species in the West Indian Ocean appears to be distinctive between different oceanographic systems. T. rufotincta has the widest distribution, covering the Persian Gulf, the Red Sea and the East African coast and absent from South Africa and southern Madagascar. T. reni is confined to southern Madagascar and adjacent waters and T. achituvi has been reported only from the Red Sea. T. 
ehsani has not been recorded in other parts of the Western Indian Ocean, except from the Iranian coast in the Gulf of Oman and it is absent from the Persian Gulf. It may be possible that T. ehsani is common in the Arabian Sea. It is essential to conduct further biodiversity surveys in the Arabian Sea region, including the west coast of India (see Wagh 1972) to ascertain the geographic distribution of T. ehsani.

\section{Acknowledgement}

The financial supports to A. Shahdadi and A. Sari were provided by the Ministry of Science, Research and Technology of Iran and office of Research affairs, University of Tehran. B.K.K.Chan was supported from the Career Development Award by Academia Sinica, Taiwan (AS-98-CDA-L15) and a grant from the National Science Council, Taiwan (NSC-99-2621-B-001-007-MY3). The authors would like to thank the SEM unit of the Academia Sinica, Taiwan for preparation of materials for SEM studies.

\section{References}

Achituv Y, Barnes H (1978) Some observations on Tetraclita squamosa rufotincta Pilsbry. Journal of Experimental Marine Biology and Ecology 31: 315-324. doi: 10.1016/00220981(78)90066-7

Appelbaum L, Achituv Y, Mokady O (2002) Speciation and the establishment of zonation in an intertidal barnacle: specific settlement vs. selection. Molecular Ecology 11: 1731-1737. doi: 10.1046/j.1365-294X.2002.01560.x

Bruguière M (1789) Encyclopédie méthodique: Historie naturelle des Vers 1: 158-173.

Chan BKK, Tsang LM, Chu KH (2007a) Cryptic diversity of the Tetraclita squamosa complex (Crustacea: Cirripedia) in Asia: Description of a New Species from Singapore. Zoological Studies 46: 46-56.

Chan BKK, Tsang LM, Ma KY, Hsu C-H, Chu KH (2007b) Taxonomic revision of the acorn barnacles Tetraclita japonica and Tetraclita formosana (Crustacea: Cirripedia) in East Asia based on molecular and morphological analysis. Bulletin of Marine Science 81: 101-113.

Chan BKK, Tsang LM, Chu KH (2007c) Morphological and genetic differentiation of the acorn barnacle Tetraclita squamosa (Crustacea, Cirripedia) in East Asia and description of a new species of Tetraclita. Zoologica Scripta 36: 79-91. doi: 10.1111/j.14636409.2007.00260.x

Chan BKK, Høeg JT, Garm A (2008) Setal morphology and setation patterns of barnacle cirri: adaptations and implications for thoracican evolution. Journal of Zoology (London) 275: 294-306. doi: 10.1111/j.1469-7998.2008.00441.x

Chan BKK, Hsu C-H, Tsai P-C (2009) Morphology and distribution of the acorn barnacle Tetraclita reni nom. nov. (Crustacea: Cirripedia) in Madagascar and adjacent waters. Zootaxa 2019: 57-68. 
Darwin C (1854) A monograph on th subclass Cirripedia with figures of all the species. The Balanidae, the Verruciade, etc. Royal Society, London, 684 pp.

Gruvel A (1903) Révision des Cirrhipèdes appartenant a la collection du Museum d'Histoire

Naturelle. Nouvelles Archives du Museum D’Histoire Naturelle de Paris sér. 4(5): 95-170.

Jones DA (1986) A Field Guide to the Sea Shore of Kuwait and the Arabian Gulf. University of Kuwait and Blandford Press, Poole, UK.

Linnaeus C (1758) Systema Naturae. Holmiae, Editio Decia, Re-formata Vol. 1, 824 pp.

Newman WA, Ross A (1976) Revision of the balanomorph barnacles; including a catalogue of the species. Memoirs of the San Diego Society of Natural History 9: 1-108.

Pilsbry HA (1916) The sessile barnacles (Cirripedia) contained in the collection of the U.S.

National Museum: including a monograph of the American species. Bulletin of the United States National Museum 93: 241-353.

Ren X (1989) On a collection of Cirripedia Thoracica from Madagascar and adjacent waters. Bulletin of the Museum national d'Histoire naturelle, Paris 4e ser section A 2: 431-468.

Ross A (1999) Studies on the Tetraclitidae (Cirripedia: Balanomorpha); new species of Tetraclita from the Red Sea. Pakistan Journal of Marine Science 8: 41-53.

Schumacher CF (1817) Essai d'un nouveau système des habitations des vers testacés. Copenhagen.

Shahdadi A (2007) Taxonomy and Biogeography of Intertidal Barnacles (Crustacea, Cirripedia) of the Persian Gulf and the Gulf of Oman. Unpublished M.Sc. thesis, University of Tehran.

Shahdadi A, Sari A (2011) Chthamalid barnacles (Cirripedia: Thoracica) of the Persian Gulf and Gulf of Oman, Iran. Journal of the Marine Biological Association of the United Kingdom 91(3): 75-753. doi: 10.1017/S0025315410001803

Southward AJ, Newman WA (2003) A review of some Indo-Malayan and western Pacific species of Chthamalus barnacles. Journal of the Marine Biological Association of the United Kingdom 83: 797-812. doi: 10.1017/S0025315403007835h

Utinomi H. (1969) Cirripedia of the Iranian Gulf. Videnskabelige Meddelelser fra Dansk Naturhistorisk Forening I Københaven, 132: 79-94.

Wagh AB (1971) Dispersal of intertidal sessile barnacle Tetraclita squamosa rufotincta (Pilsbry) by water current. Journal of the Bombay Natural History Society 71: 322-324.

Wagh AB (1972) On the southern limits of Tetraclita squamosa rufotincta (Pilsbry) (Cirripedia, Thoracica) along the west coast of India. Current Science 41: 38-39. 